\title{
Effects of Live Food Feeding on Growth Performance and Some Histological Parameters of Herotilapia multispinosa and Amatitlania nigrofasciata
}

\author{
Deniz D. Tosun (D), Melih Simsar
}

Cite this article as: Tosun, D.D., Simsar, M. (2018). Effects of Live Food Feeding on Growth Performance and Some Histological Parameters of Herotilapia multispinosa and Amatitlania nigrofasciata. Aquatic Sciences and Engineering, 33(4): 131-137.

Department of Aquaculture, istanbul University, Faculty of Aquatic

Sciences, İstanbul, Turkey

Submitted:

04.07.2018

Accepted:

26.09.2018

Correspondence:

Deniz D. Tosun

E-mail:

deniztosun@gmail.com

ddt@istanbul.edu.tr

(C) Copyright 2018 by Aquatic

Sciences and Engineering

Available online at

ase.istanbul.edu.tr

\begin{abstract}
Aquarium fish feeding is an expensive hobby. Live foods such as Artemia are highly expensive and widely used. Therefore, aquarists look for alternative live food sources to feed their fish. Nematodes and annelids are good sources of protein and are easy to produce. In this study, we evaluated the effects of nematode and annelid feeding on the on growth performance and some histological parameters of Herotilapia multispinosa and Amatitlania nigrofasciata compared with commercial feeds. A. nigrofasciata fish groups fed with live and commercial food showed the highest survival rates of $91 \%$ and $100 \%$, respectively. However, $H$. multispinosa fish groups fed with live food showed inhibited growth. Histologic examination of the liver and intestines revealed negative effects on these aquarium fish. Thus, right feeding regime practices should be established for using nematodes and annelids as fish food sources.
\end{abstract}

Keywords: Annelids, nematodes, aquarium fish, Herotilapia multispinosa, Amatitlania nigrofasciata

\section{INTRODUCTION}

Aquariums are generally accepted as a hobby all around the world. Yet, the aquarium fish industry is a very big and important industry in terms of fish production. The aquarium fish trade costs about 659 million US dollars in the world. Supporting industries like fish feeds, filters, water chemicals and other equipment totals up to a 30 billion US dollars industry. Over 4000 freshwater and 1400 marine species of fish are in circulation for aquarium trade and an estimated 1 billion fish is sold every year (Whittington and Chong 2007, Tolon and Emiroğlu, 2014). It is evident that, aquarium fish are very cost effective compared to other fisheries products (Galib and Mohsin 2010, Saxena 2003). Growing aquarium industry increased the demand for ornamental fish which increased the need for aquarium fish culture establishments. Presently, freshwater species used in aquariums are $90 \%$ cultured and 10\% wild captured whereas marine species are only $5 \%$ cultured. Yet marine fish are much more profitable and sought for by the hobbyists (Hekimoğlu 2005; Gümüş et al. 2014; Türkmen and Aktuğ, 2011).

Cichlid species are the most common species used for aquariums as well as the most cultured aquarium species. Most of them are preferred by the middle class and low income consumers for their affordable prices. One of the most important problems for these consumers is the cost of feeding. Quality feeds are important for both fish producers and home consumers for fish health, breeding and growth performance and visual quality (Naylor et al., 2009). High quality feeds are available as commercial products with high prices. Especially, larval feeding products like artemia and granulated feeds are very high priced feeds which are commonly used. The most used live food for larval feeding is Artemia sp. Which is 
collected from the salt lakes around the world like Utah, Great salt Lake, Iran, Urmia Lake, Izmir, Çamaltı Saltworks. These sources are limited and dependent on natural stocks and growing need for artemia by aquaculture hatcheries increases the prices every year (Korkut et al., 2003; Tosun et al., 2015). This high prices results in the need for alternative live foods with low production costs.
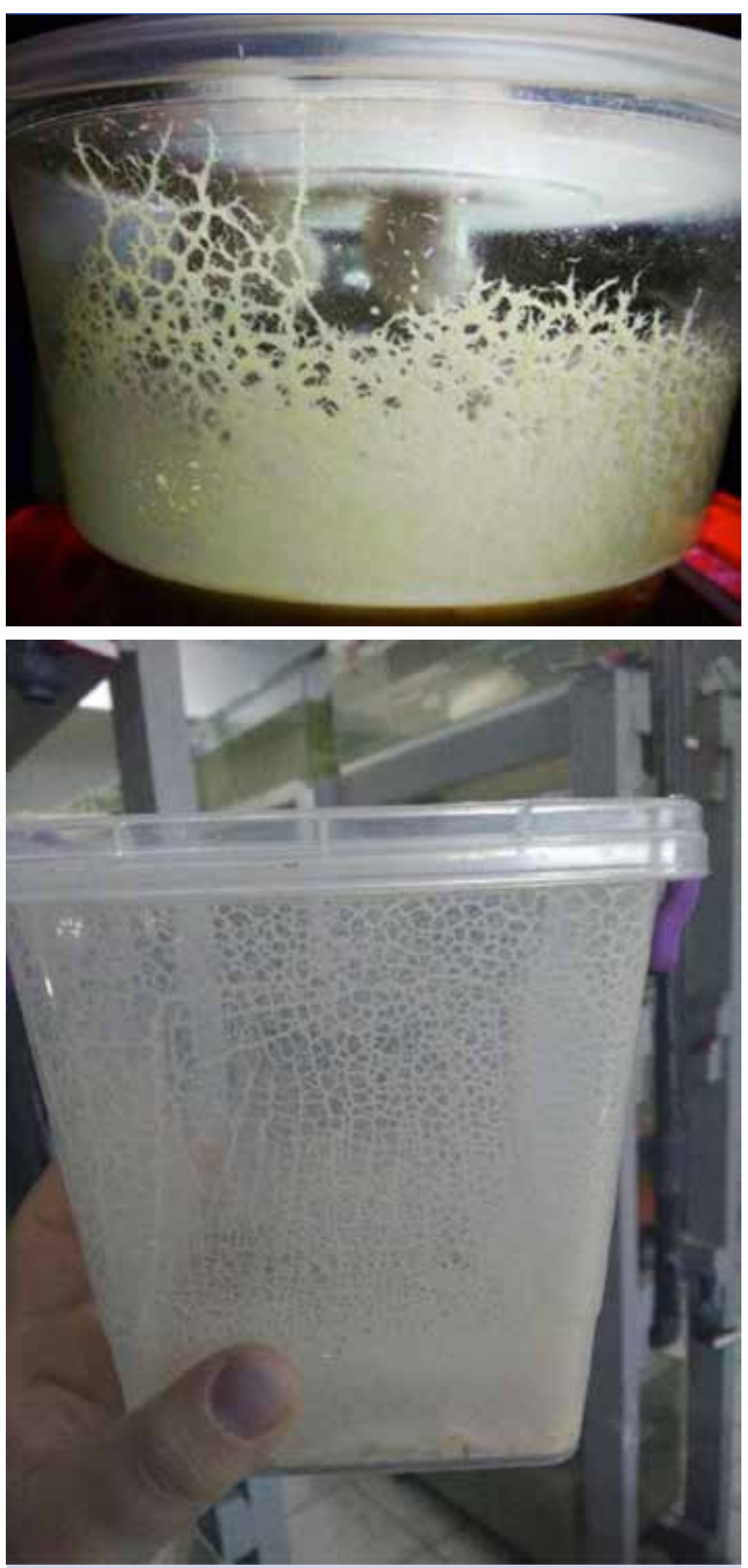

Figure 1. Nematod culture media and climbing nematodes on the walls
Nematodes and Annelids are important alternatives for fish feeding with their low production costs and nutritional qualities. Panagrellus redivivus is a free living non-parasitic nematode which can be suitable for larval feeding. $P$. redivivus is the preferred nematode species for most of the aquarists with their ease of production and nutritional composition (Bruggemann, 2012). Enchytraeus sp. are annelid species used in aquarium fish feeding. Easy and economic growth of these live foods gets the attention of both fish producers and scientists for further research and production techniques (Tosun et al., 2015; Şahin et al., 2017). Starter culture costs for these live feeds are low and they are easily produced with low cost raw materials like water and oatmeal. One of the important aspect of producing annelids and nematodes is the ease of nutritional composition enhancement. Inclusion of fish meal and oil results in culture mediums results in high quality nutritional quality both for nematodes and annelids (Delbare and Dhert, 1996; Ricci, 2001; Santiago et al., 2003; Reyes et al., 2011; Schlechtriem et al., 2004; Kumlu et al., 1998; Santiago et al., 2004; Ercan et al., 2018).

In this study, we evaluated the effects of annelid and nematode feeding on Amatitlania nigrofasciata and Herotilapia multispinosa growth performances and some histologic parameters in aquariums.

\section{MATERIAL AND METHOD}

\section{Nematodes}

Panagrellus redivivus cultures used in this study were obtained from the Live Feed Laboratory of Aquaculture Department, Faculty of Aquatic Sciences, İstanbul University. P. redivivus cultures were inoculated in 11 plastic cases (Figure 1). The culture medium consisted of oat meal, water and yeast (baker's yeast) $200 \mathrm{~L}$ mixture (Tosun et al., 2015). Culture media was kept at $24^{\circ} \mathrm{C}$. 10 plastic cases were used for nematode production and all received $2 \mathrm{ml}$ starter cultures. Plastic cases were kept in Live Feed Culture Laboratory, Faculty of Aquatic Sciences. Microworms climbing the walls were harvested with a spatula to feed fish (Figure 1).

\section{Annelids}

Enchytraeus albidus was obtained from the Live Feed Laboratory of Aquaculture Department, Faculty of Aquatic Sciences, İstanbul University. E. albidus starter culture was inoculated in two $6.8 \mathrm{I}(33 \mathrm{~cm} \times 23 \mathrm{~cm} \times 9 \mathrm{~cm})$ plastic cases. Coconut turf was used as growth media with weekly additions of baby formula, milk, yoghurt and kefir (Memiş et al., 2004). Climbing worms were easily harvested and used as food (Figure 2).

\section{Control Feed}

Commercial aquarium flake feeds (AHM - Tropical mix flake) were used for control groups. Proximate composition of the feed is given in Table 1.

\section{Fish}

Herotilapia multispinosa (rainbow cichlid) and Amatitlania nigrofasciata (convict cichlid) were obtained from the Aquarium Fish Laboratory of Aquaculture Department, Faculty of Aquatic Sciences, İstanbul University. 
Forty-eight convict cichlids with $0.54 \pm 0.27 \mathrm{~g}$ mean weight (SD \pm ) and $2.8 \pm 0.53 \mathrm{~cm}$ mean length were placed in four glass aquaria (A1, A2, B1, B2, each stocked with12 fish). 44 Rainbow cichlids with $0.14 \pm 0.09 \mathrm{~g}$ mean weight $(\mathrm{SD} \pm)$ and $1.4 \pm 0.36 \mathrm{~cm}$ mean length were placed in four glass aquaria (A3, A4, B3, B4, each stocked with 11 fish).

\section{Aquariums}

A total of eight aquariums were used during the experiment. 52.5 I ( $\mathrm{L} 70 \mathrm{~cm} \times \mathrm{W} 30 \mathrm{~cm} \times \mathrm{H} 30 \mathrm{~cm}$ ) glass to glass aquariums which were part of a recirculating system with mechanic and biologic

Table 1. Proximate composition of the commercial flake feed.

\begin{tabular}{lc}
\hline Commercial feed proximate composition \\
\hline Moisture & $8 \% \max$ \\
Crude Protein & $47 \% \min$ \\
Crude Lipids & $4 \% \min$ \\
Ash & $7 \% \max$ \\
\hline
\end{tabular}

Table 2. Feeding regime and fish distribution.

\begin{tabular}{|c|c|c|c|c|}
\hline Species & Groups & 09:00 & $12: 30$ & $16: 00$ \\
\hline $\begin{array}{l}\text { Amatitlania } \\
\text { nigrofasciata }\end{array}$ & $\mathrm{A} 1$ - A2 & $\begin{array}{c}\text { Nematod + } \\
\text { Annelid }\end{array}$ & $\begin{array}{l}\text { Flake } \\
\text { feed }\end{array}$ & $\begin{array}{c}\text { Nematod + } \\
\text { Annelid }\end{array}$ \\
\hline $\begin{array}{l}\text { Amatitlania } \\
\text { nigrofasciata }\end{array}$ & $\mathrm{B} 1$ - B2 & $\begin{array}{l}\text { Flake } \\
\text { feed }\end{array}$ & $\begin{array}{l}\text { Flake } \\
\text { feed }\end{array}$ & $\begin{array}{l}\text { Flake } \\
\text { feed }\end{array}$ \\
\hline $\begin{array}{l}\text { Herotilapia } \\
\text { multispinosa }\end{array}$ & $\mathrm{A} 3-\mathrm{A} 4$ & $\begin{array}{c}\text { Nematod + } \\
\text { Annelid }\end{array}$ & $\begin{array}{l}\text { Flake } \\
\text { feed }\end{array}$ & $\begin{array}{c}\text { Nematod + } \\
\text { Annelid }\end{array}$ \\
\hline $\begin{array}{l}\text { Herotilapia } \\
\text { multispinosa }\end{array}$ & B3 - B4 & $\begin{array}{l}\text { Flake } \\
\text { feed }\end{array}$ & $\begin{array}{l}\text { Flake } \\
\text { feed }\end{array}$ & $\begin{array}{l}\text { Flake } \\
\text { feed }\end{array}$ \\
\hline
\end{tabular}

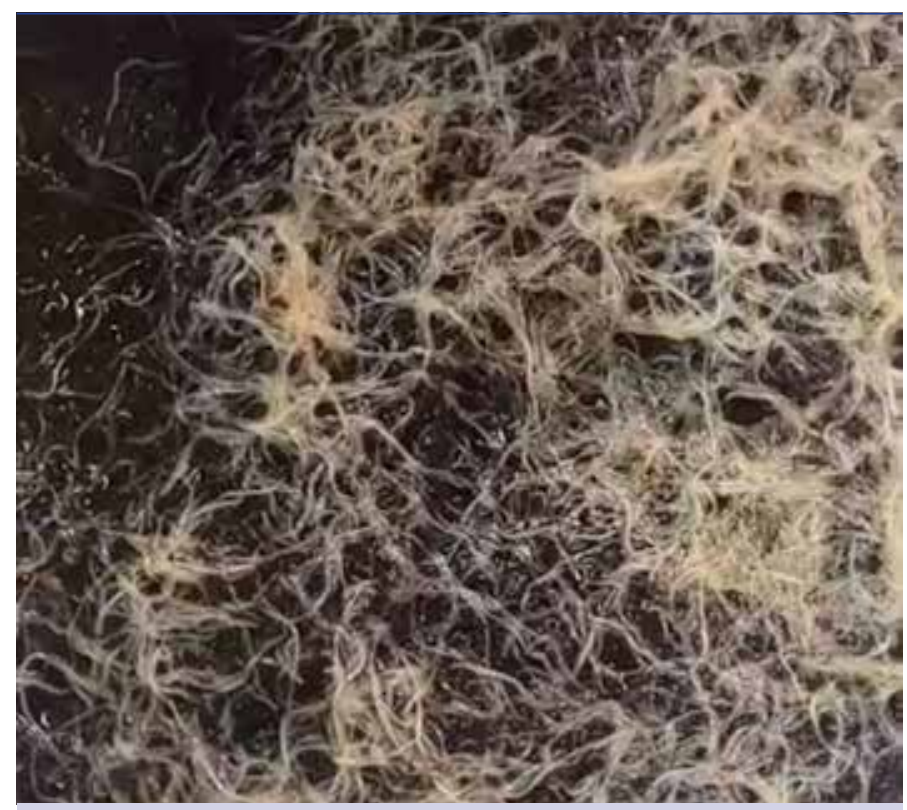

Figure 2. Annelid culture media filtration were used. Water depth was $25 \mathrm{~cm}$ and water temperature was $22 \pm 2^{\circ} \mathrm{C}$ during the experiment. Aquariums were labeled as $A 1, A 2, A 3, A 4, B 1, B 2, B 3, B 4$. This study has been designed as 2 parallel for every group.

\section{Feeding Regime}

$A 1-A 2$ and B1-B2 aquariums were stocked with convict cichlids, A3-A4 and B3-B4 aquariums were stocked with rainbow cichlids. A group aquariums were fed with live food twice a day (ad-libitum) at 09.00 and 16.00 and with flake feeds at 12:30. B group aquariums were fed only flake feeds at the same hours (Table 2).

\section{Measurements}

The experiment lasted for 3 months (90 days). Fish were measured for length by a ruler ( $\mathrm{mm}$ ) and weight (Digital scale, $0.01 \mathrm{~g}$ ) for every 30 day intervals. Data was analyzed using Student's Ttest (Excel 2013, Microsoft).

\section{Histological Examination}

Randomly selected fish (3 from each group) were examined histologically. Histologic changes in liver and intestines were targeted. Fish were anaesthetized with 2-phenoxiethanol. After ventral incision, all fish was fixated in $10 \%$ formalin solution. Processed samples were placed in paraffin and cut into $4-5 \mu \mathrm{m}$ cross-sections. Cross-sections were stained by Hematoxylin \& Eosin method and examined under microscope (Culling, 1972).

\section{RESULT AND DISCUSSION}

\section{Weight and Length Measurements}

\section{Weight Measurements}

Mean weight gain results for live food fed groups are given in Figure 3.

Convict cichlids received live foods better than rainbow cichlids. Rainbow cichlids showed weight loss in the last period during the experiment.

Mean weight gain results for commercial flake feed fed groups are given in Figure 4.

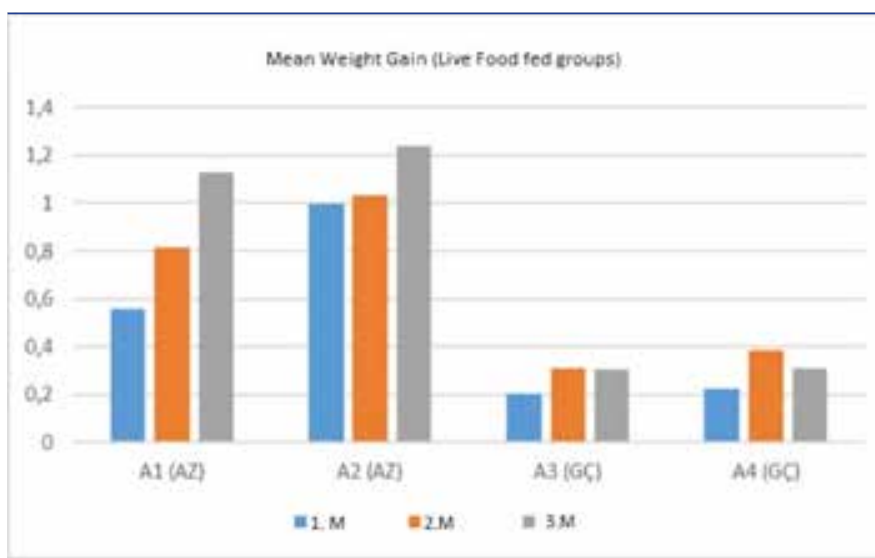

Figure 3. Mean weight gain comparison between live feed fed groups 
Both fish species fed with commercial feeds had continuous growth in weight till the end of the experiment. Although A1A2 groups have better results in terms of mean weight gain, live food feeding did not have statistically important differences with B1-B2 groups ( $>>0.05)$. Yet, when compared with A2-A3, B3B4 groups have statistically better mean weight gain. Hoyland (2015) achieved continuous growth in labrus bergylta larvae with

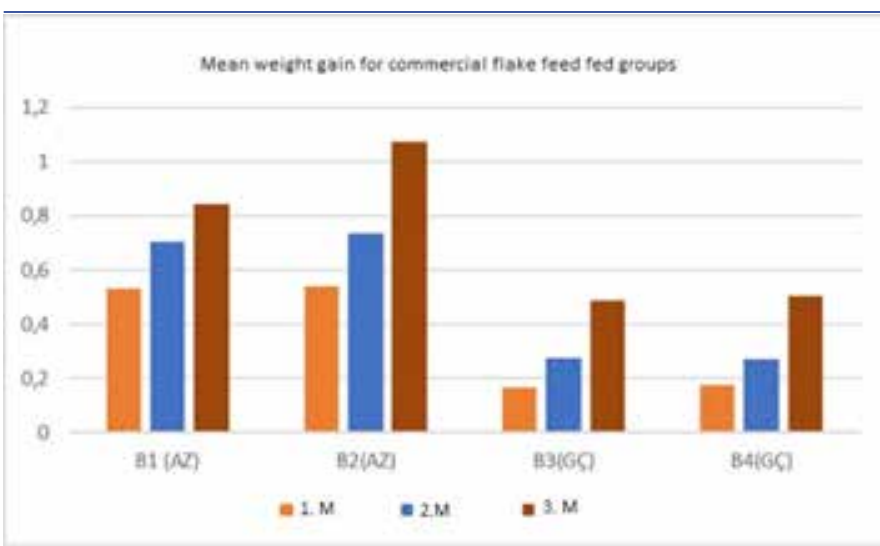

Figure 4. Mean weight gain results for commercial flake feed fed groups
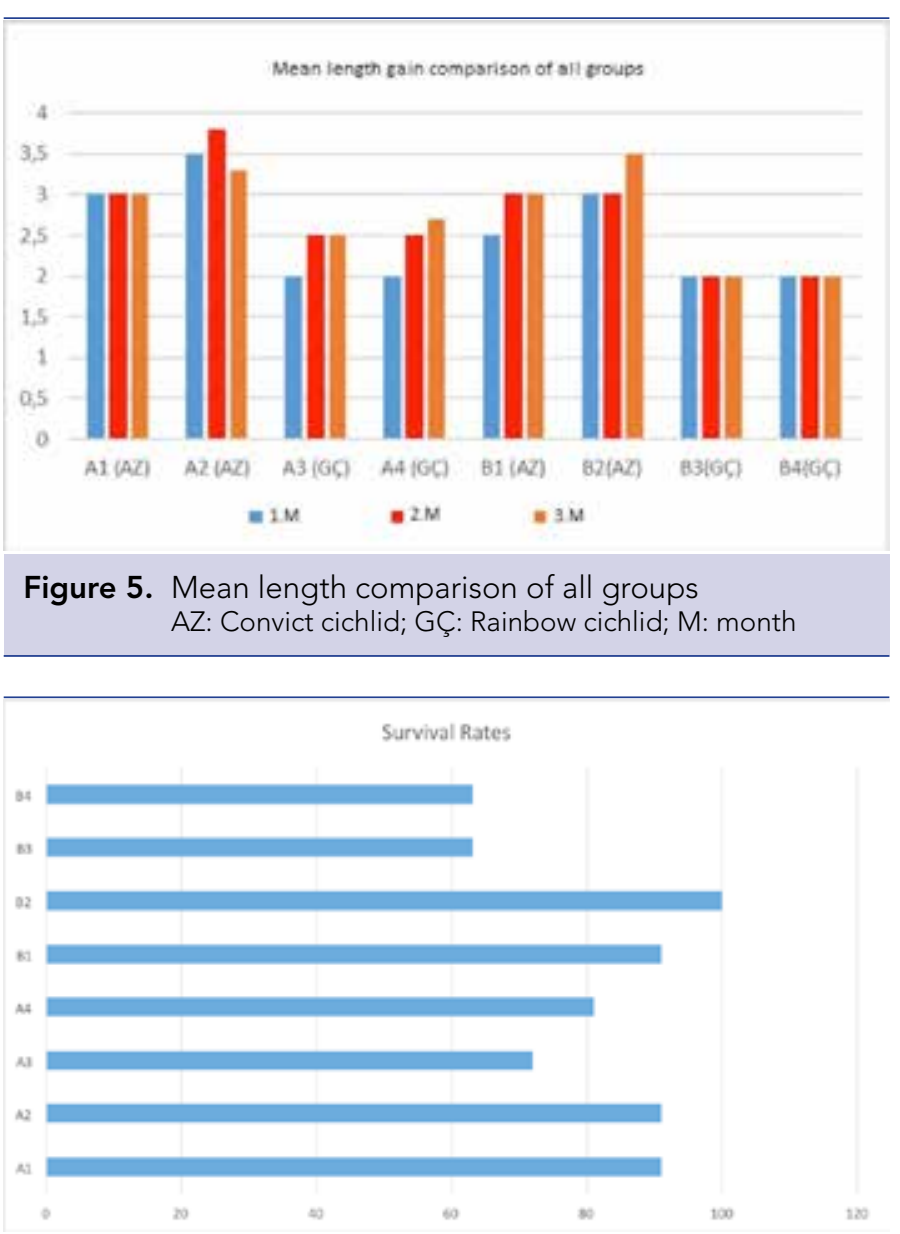

Figure 6. Survival rates (\%) for the groups at the end of the trial live feeds which was similar for convict cichlids response to live feeds in our study. We can reach to the conclusion that rainbow cichlids weight gain is inhibited with live food feeding. Mohseni et al. (2012) reported that Huso huso larvae, fed with live foods showed less growth in comparison to granulated pellets which is a similar result to our results with rainbow cichlids.

\section{Length Measurements}

Mean length measurements for all groups are given in Figure 5.

As it is evident in the given table, all groups except B3-B4 showed growth in length during the trial period. Commercial feed fed groups did not have significant differences in terms of growth in length compared to nematode and annelid fed groups.

\section{Survival Rate}

Calculated survival rates are given in Figure 6. Highest survival rates were calculated for A1, A2 (91\%) and B1, B2 (91\% and 100\%) groups. Lowest survival rates were calculated for $63 \%$ for $\mathrm{B} 3$ and B4 (Figure 6).
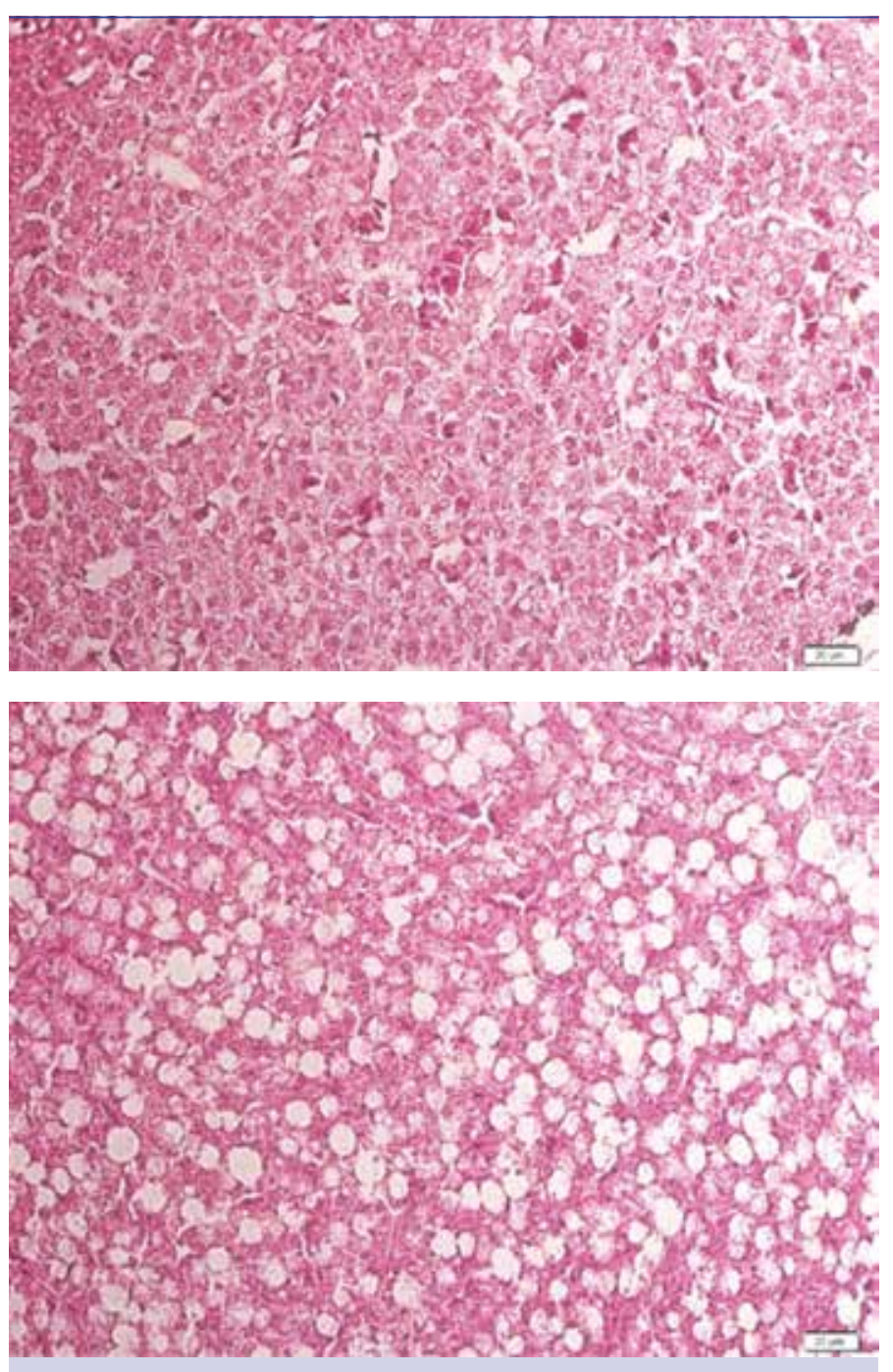

Figure 7. Lipid vacuoles in hepatocyte cells in cross sections of livers from live food fed groups Left; convict cichlid; right; rainbow cichlid 

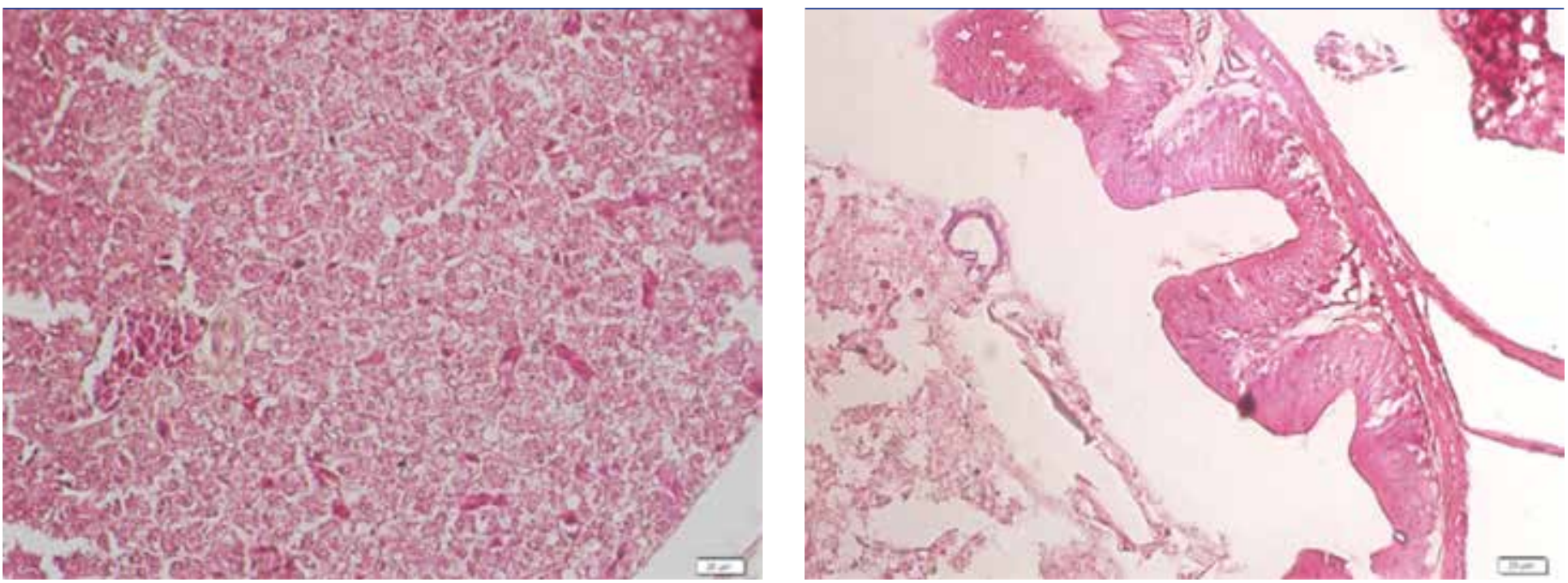

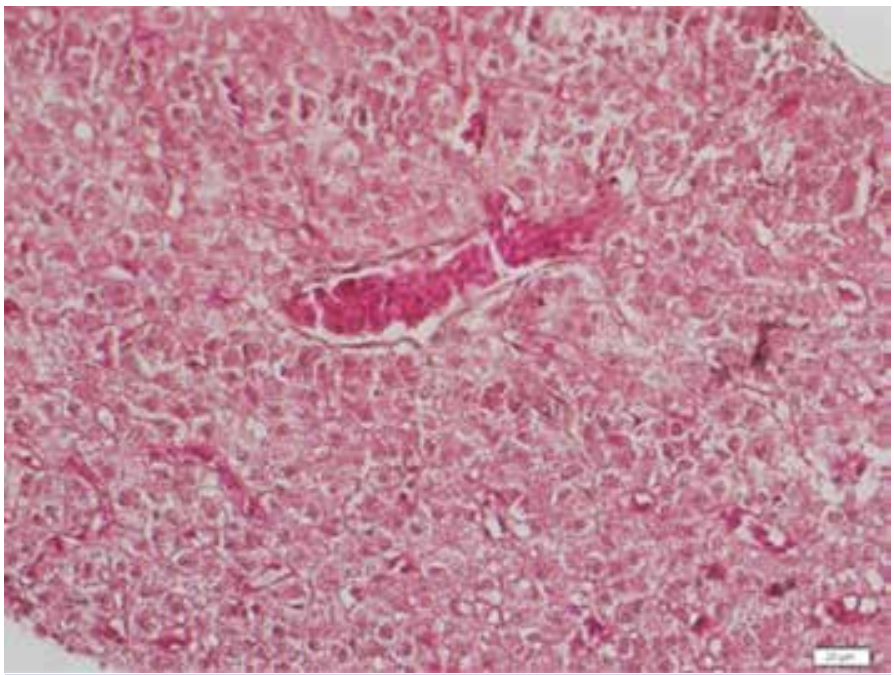

Figure 8. Healthy liver cross sections from commercial food fed groups without lipid accumulation Left; convict cichlid; right; rainbow cichlid

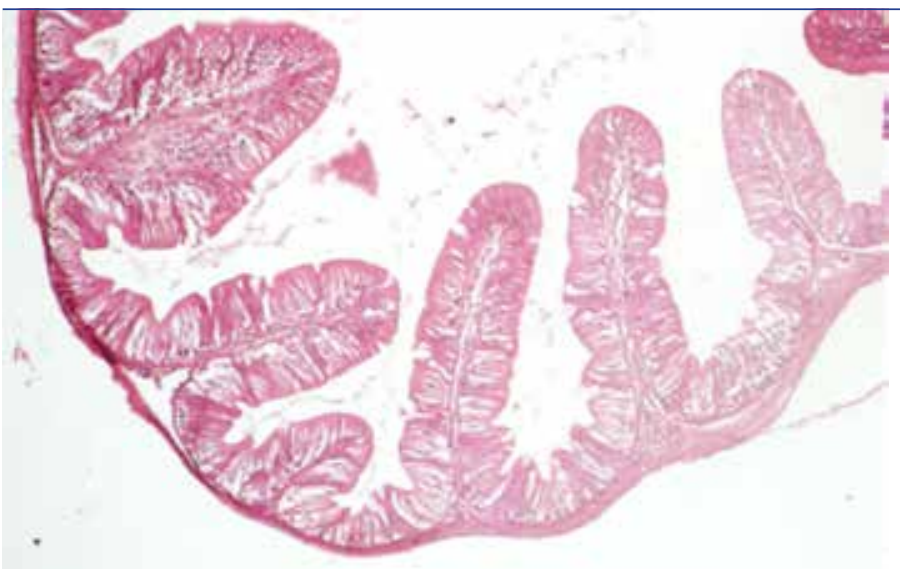

Figure 10. Healthy intestinal cross sections from commercial food fed groups Left; convict cichlid; right; rainbow cichlid

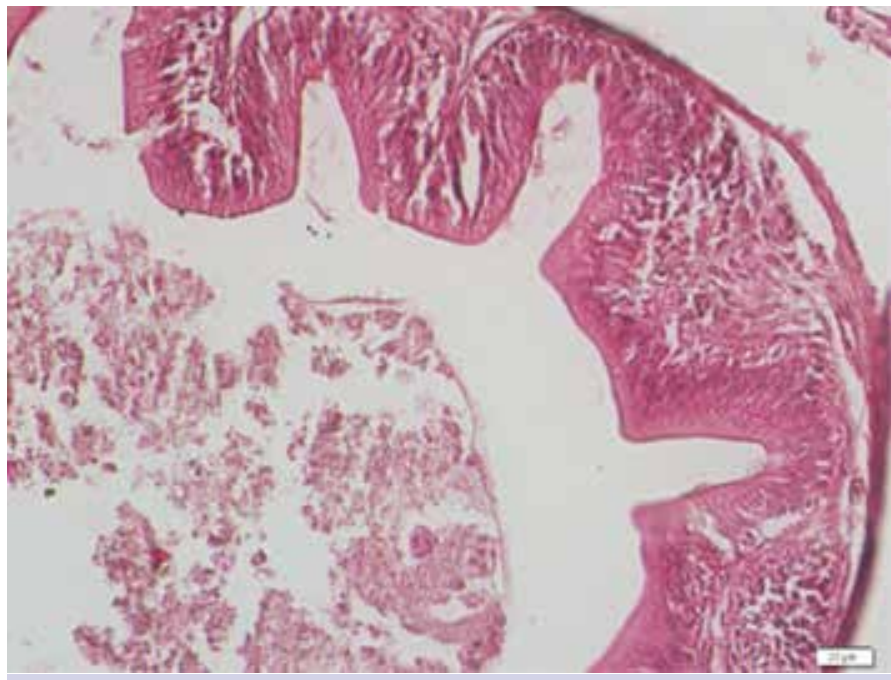

Figure 9. Cross sections of intestines from live food fed groups Left; convict cichlid; right; rainbow cichlid 


\section{Histological examination}

A1, A2, A3 and A4 liver cross sections showed lipid vacuoles in hepatocyte cells. This showed that live food feeding resulted in lipids accumulation in liver cells for both convict cichlids and rainbow cichlids (Figure 7 ).

Contrary to the live food fed groups, commercial food fed groups (B1, B2, B3 and B4) had healthy liver cross sections (Figure 8).

\section{Intestinal Examination}

Cross sections from the intestines showed that live food fed groups ( $A 1, A 2, A 3$ and $A 4)$ had damaging effect. Villus were shortened with absorptive vacuoles on the tips, lamina propria were widened, and ruptures in serosa were found (Figure 9).

In cross sections from commercial food fed groups, intestines showed much healthier characteristics. Villus were longer, enterocytes had centered nucleus, lamina propria were not widened and goblet cells were present (Figure 10).

\section{CONCLUSION}

Live foods like nematodes and annelids which are widely used in aquarium fish maintenance and production are important alternatives with their ease of production and low costs. Alternative protein sources are gaining importance with increasing aquaculture production all around the world. P. redivivus is mainly important with its fast growth, easy mass production and ease of use as food. In addition, nutritional enhancement is possible. Brüggeman (2012), mentions that small size productions are easily adopted to industrial size production systems. Wilkenfeld (1984), points out that, production of these live foods can be more economical in comparison with artemia which presently is a very high priced commodity. As we demonstrated in our study, growth performances and survival rates of the fish fed with alternative live foods are not different compared with commercial feeds. This shows that, cheaper alternatives can be used for aquarium fish instead of expensive commercial products.

Our histological findings show that, amount of live feed used is important for healthy individuals. Raised amount of live feeds may result in internal damages to fish. Enhancing the live feeds or balancing the amount in the feeding regime should be evaluated in future studies. Culture mediums to produce suitable nematodes or annelids has to be formulated for better nutritional quality and healthy aquarium fish.

Acknowledgements: Authors would like to thank Talya Akar, Dr. Çiğdem Ürkü and Merve Tınkır and the academic staff of Aquaculture and Fish Disease Department, Faculty of Fisheries, Istanbul University for their help and support during the experimental period.

Conflict of Interest: The authors have no conflicts of interest to declare.

\section{REFERENCES}

Brüggemann, J. (2012). Nematodes as Live Food in Larviculture - A Review. Journal of the World Aquaculture Society, Doi:10.1111/j.17497345.2012.00608.x [CrossRef]

Culling CFA (1974). A Handbook of Practical Histochemical and Histopathological Techniques. Ed 3. Butterworth and Company, Ltd. London, ISBN: 97814831647931972 . [CrossRef]
Delbare, D., Dhert, P. (1996). Nematodes. In: Manual on the production and use of live food for aquaculture. Lavens, P; Sorgeloos, P. (eds.) FAO Fisheries Technical Paper. No. 361. Rome, FAO. 289-292.

Ercan E., Hacisa M., Cengiz, S. (2018). Effects of Different Types of Feed And Bedding Material to Population Growth and Biochemical Composition On White Worm (Enchytraeus albidus Henle, 1837). International Conference on Agricultural Science-2018, Bulgaria.

Galib, S., Mohsin, A. (2010). Exotic ornamental fishes of Bangladesh. Bangladesh Journal of Progressive Science and Technology, 8(2): 255-258.

Gümüş, E., Kanyilmaz, M., Gülle, İ., Sevgili, H. (2014). Antalya bölgesindeki süs balığı üreten işletmelerin yapısal ve teknik analizi: II. Teknik özellik ve pazarlama durumları, Biyoloji Bilimleri Araştırma Dergisi, 6(2): 32-38.

Hekimoğlu, M.A., Şenol, Ş., Saygı, H. (2005). A study about determining general profile of aquarium facilities at Izmir county's. (in Turkish with English abstract). Ege Journal of Fisheries and Aquatic Sciences, 22(1-2): 119-123.

Høyland, O.S. (2015). The effect of different live feeds and water qualities on growth, survival, ossification and skeletal anomalies of ballan wrasse (Labrus bergylta) larvae. 74. Thesis, Norwegian University of Science and Technology, Department of Biology.

Yıldırım Korkut, A., Yıldııı, Ö. (2003). Türkiye'de su ürünleri yetiştiriciliği ve yetiştiricilikte alternatif yem kaynakları. Ege Üniversitesi Su Ürünleri Dergisi, 20(1-2): 247-255.

Kumlu, M., Fletcher, D.J., Fisher, C.M., (1998). Larval pigmentation, survival and growth of Penaeus indicus fed the nematode Panagrellus redivivus enriched with astaxanthin and various lipids. Aquaculture Nutrition, 4; 193-200. [CrossRef]

Memiş, D., Çelikkale, M. S., \& Ercan, E. (2004). The Effect of Different Diets on the White Worm (Enchytraeus albidus Henle, 1837) Reproduction. Turkish Journal of Fisheries and Aquatic Sciences, 4: 5-7.

Mohseni, M., Pourkazemi, M., Hassani, S. H., Okorie, O.E., Min, T.S., Bai, S.C. (2012). Effects of different three live foods on growth performance and survival rates in Beluga (Huso huso) larvae. Iranian Journal of Fisheries Sciences, 11(1), 118-131.

Naylor, R.L., Hardy, R.W., Bureau, D.P., Chiu, A., Elliott, M., Farrell, A.P., Nichols, P.D. (2009). Feeding aquaculture in an era of finite resources. Proceedings of the National Academy of Sciences, 106(36): 15103-15110. [CrossRef]

Reyes, O. S., Duray, M. N., Santiago, C. B., Ricci, M. (2011). Growth and survival of grouper Epinepheluscoioides (Hamilton) larvae fed freeliving nematode Panagrellus redivivus at first feeding. Aquaculture International, 19: 155-116. [CrossRef]

Ricci, M. (2001). Development of bio-encapsulated feed for larval fish ased on nutritionally enriched nematodes - NEMATODES, Summary of The Final Report. 4th Framework Programme, Joint Research Project, Project No: IC18980333, 1-3.

Santiago, C.B., Gonzal, A.C., Ricci, M., Harpaz, S., (2003). Response of bighead carp Aristichthys nobilis and Asian catfish Clarias microcephalus larvae to free-living nematode Panagrellus redivivus as alternative feed. Journal of Applied Ichthyology, 19: 239-243. [CrossRef]

Santiago, C.B., Ricci, M., Reyes-Lampa, A., (2004). Effect of nematode Panagrellus redivivus density on growth, survival, feed consumption and carcass composition of bighead carp Aristichthys nobilis (Richardson) larvae. Journal of Applied Ichthyology, 20: 22-27. [CrossRef]

Şahin, D., Öz, M., Karsli, Z., Aral, O., Bahtiyar, M. (2017). Effect of frozen white worm (Enchytraeus sp .) on growth of platy (Xiphophorus maculatus Günther , 1866), Turkish Journal of Aquatic Sciences, 71-75. [CrossRef]

Saxena, A. (2003). Aquarium management: Daya Publishing House. ISBN 10: 8170352843 ISBN 13: 9788170352846.

Schlechtriem, C., Ricci, M., Focken, U., Becker, K. (2004). The suitability of the free-living nematode Panagrellus redivivus as live food for first- feeding fish larvae. Journal of Applied Ichthyology, 20: 161-168. [CrossRef] 
Tolon, T., Emiroğlu, D. (2014) Akvaryum baliklari pazar yapisi ve tüketici tercihlerinin değerlendirilmesi. I. Ulusal Akvaryum Balıkçılığı ve sorunları Çalıştayı Sonuç Raporu, Antalya.

Tosun, D.D., Türetken, P.S.Ç., Tosun, Ş.Y. (2015). Larva Beslenmesinde Kullanılan Mikrokurtların (Panagrellus Redivivus) Besin Kompozisyonlarının Araştırılması. İstanbul University Journal of Fisheries and Aquatic Sciences, 30(1): 1-10.
Türkmen, G., Aktuğ, A.M. (2011). İzmir ili 'nde Deniz Akvaryumu Sektörü ve Ele Alınan İthal Balık Türlerinin Araştırılması, Ege Journal of Fisheries and Aquatic Sciences, 28(2): 59-64

Whittington, R., Chong, R. (2007). Global trade in ornamental fish from an Australian perspective: the case for revised import risk analysis and management strategies. Preventive Veterinary Medicine, 81(1): 92-116. [CrossRef] 